\title{
Bimbingan Karir Farid Poniman dan Relevansinya dengan Konsep Islam: Telaah STIFIn Test
}

\author{
Hermi Pasmawati \\ Bimbingan dan Konseling Islam \\ Institut Agama Islam Negeri Bengkulu
}

Korespodensi dengan Penulis:

Hermi Pasmawati, Telp: 081374523261

E-mail: hermipasmawati@iainbengkulu.ac.id

Keywords:
Career guidance,
STIFIn Test,
Islam

Kata kunci: Bimbingan Karir, STIFIn Test, Islam

\begin{abstract}
In the process or stages of career guidance can not be separated from the stages of career exploration. One of the things that needs to be explored from within an individual is basic characteristics. STIFIn Test is a test instrument that can reveal a person's basic abilities or intelligence from an early age. This study examines the relevance between the stages of the career guidance process as seen from the process of identifying the intelligence machine possessed through the process of scanning the fingerprints of the ten fingers with the direction of the chosen field or profession and their relevance to the concept of potential in Islam. The writing method uses literature review by comparing, analyzing and connecting STIFIn theory theory studies with the stages and processes of career guidance. This study found the results of the scanning of the ten fingerprints which produced nine types of individual characteristics, used as a basis in the process of entering the study, choosing majors or study programs or scientific fields and professions in accordance with the intelligence machine they have. In Islam, humans who are born into the world are the most perfect creatures. Furthermore in the hadith also explained that humans are born in a state of nature. Some commentators interpret the word fitrah as latent potential or basic potential brought by humans from birth. From this explanation it is very relevant that basically humans have the basic potential or genetic potential that has been provided from birth, to be developed in carrying out their professions and careers.
\end{abstract}

\begin{abstract}
Abstrak
Dalam proses atau tahapan bimbingan karir tidak terlepas dari tahapan ekplorasi karir. Salah satu hal yang perlu dieksplorasi dari dalam diri individu adalah karakteristik dasar. STIFIn Test merupakan Instrumen tes yang dapat mengungkap kemampuan atau kecerdasan dasar seseorang sejak usia yang masih sangat dini. Studi ini mengkaji relevansi antara tahapan proses bimbingan karir dilihat dari proses identifikasi mesin kecerdasan yang dimiliki melalui proses pemindaian sidik jari dari kesepuluh jari tangan dengan arah bidang atau profesi yang dipilih serta relevansinya dengan konsep potensi dalam Islam.
\end{abstract}


Metode penulisan menggunakan kajian pustaka dengan cara membandingkan, menganalisis serta menghubungkan kajian teori STIFIn Test dengan tahapan dan proses bimbingan karir. Studi ini menemukan hasil pemindaian dari sidik jari kesepuluh tangan yang menghasilkan sembilan tipe karakteristik individu, dijadikan sebagai dasar dalam proses memasuki studi, memilih jurusan atau program studi atau bidang keilmuan dan profesi yang sesuai dengan mesin kecerdasan yang dimiliki. Dalam Islam bahwa manusia yang dilahirkan ke dunia merupakan makhluk yang paling sempurna. Selanjutnya dalam hadis juga dijelaskan bahwa manusia dilahirkan dalam keadaan fitrah. Beberapa Ahli tafsir memaknai kata fitrah sebagai potensi laten atau potensi dasar yang dibawa manusia sejak lahir. Dari penjelasan tersebut sangat relevan sekali bahwa manusia memiliki potensi dasar atau potensi genetis yang telah dibekali sejak lahir, untuk dapat dikembangkan dalam menjalankan profesi dan karirnya.

\section{PENDAHULUAN}

Setiap individu memiliki potensi atau kelebihan dan kekuatan masing-masing yang sangat unik antara individu. Memiliki karakter dan kepribadian, keberagamanan minat dan kecenderungan yang akan bermuara kepada arah minat bakat dan potensi yang unggul dari diri individu tersebut. Setiap insan yang terlahir ke dunia adalah insan yang terpilih yang telah berkompetisi dengan ratusan juta sperma yang ada. Tapi, hanya satu yang berhasil menembus sel telur yang akan berproses menjadi manusia. Ini menjadi suatu tanda bahwa setiap insan yang terlahir adalah sang pemenang, terlepas bagaimanapun rupa dan bentuk setelah di alam dunia. Sebagaimana Allah SWT berfirman

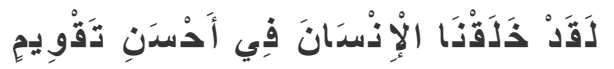

"Sesungguhnya Kami telah menciptakan manusia dalam bentuk yang sebaik-baiknya (Q.S. At-Tin: 4)."

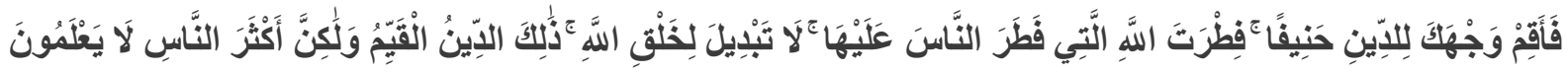

"Maka hadapkanlah wajahmu dengan lurus kepada agama Allah; (tetaplah atas) fitrah Allah yang telah menciptakan manusia menurut fitrah itu. Tidak ada perubahan pada fitrah Allah. (Itulah) agama yang lurus; tetapi kebanyakan manusia tidak mengetahui (Q.S Ar-Rum: 30)."

Q.S At-Tin ayat 4 dan Ar-Rum ayat 30 menjelaskan tentang fitrah manusia sebagai suatu perangkat yang diberikan oleh Allah yaitu kemampuan dasar. Fitrah tersebut memiliki kecenderungan untuk berkarya. Manusia diciptakan Allah SWT dalam struktur yang paling 
tinggi. Selanjutnya Ayat di atas juga sangat relevan dengan Hadis Riwayat Bukhari ${ }^{1}$ tentang kefitrahan dasar manusia, yaitu sebagai berikut;

“Tidak ada orang yang dilahirkan (di dunia) kecuali dalam keadaan fitrah. Maka orang tualah yang akan menjadikannya Yahudi, Nasrani atau Majusi. Sebagaimana binatang ternak yang telah melahirkan anak-anaknya, apakah engkau membersihkan unta yang termasuk binatang ternak? Kemudian Abu Hurairah RA mengatakan: bacalah jika kalian semua menghendakinya; (tetaplah atas) fitrah Allah SWT yang menciptakan manusia menurut fitrah itu."

Shanminan Zain menafsirkan bahwa fitrah adalah potensi laten atau kekuatan yang terpendam yang ada dalam diri manusia yang di bawa sejak lahir. ${ }^{2}$ Menurut alAuzal, fitrah merupakan kesucian dalam jasmani dan rohani. Ramayulis berpandangan bahwa fitrah adalah kemampuan dasar bagi perkembangan manusia yang dianugrahkan oleh Allah SWT yang tidak ternilai harganya dan harus dikembangkan agar manusia dapat mencapai tingkat kesempurnaan. ${ }^{3}$ Secara lebih komprehensif, Muhammad bin Asyur mendefinisikan fitrah (makhluk) adalah bentuk lain dari sistem yang diwujudkan Allah SWT pada setiap makhluk. Sedangkan fitrah yang berkaitan dengan manusia adalah yang diciptakan Allah SWT pada manusia yang berkaitan dengan kemampuan jasmani dan akalnya. ${ }^{4}$

Selanjutnya pengenalan karakteristik seseorang juga dapat dilihat dari tampilan fisik yang ditampilkan dengan melihat beberapa sampel orang-orang yang sudah sukses dengan bakat yang menonjol seperti kondisi mata bundar yang tajam, ukuran tengkorak kepala yang besar, dan bentuk kening atau lebarnya kening sebagai tanda kesuksesan seseorang. Dapat juga melalui beragam alat tes bakat dan minat, yang berfungsi untuk mendeteksi seseorang mampu melakukan bidang pekerjaan tertentu, melalui alat tes ini biasanya dapat terungkap kemampuan bekerja di bawah tekanan yang tinggi, kemampuan untuk menyelesaikan masalah yang sangat rumit, tingkat kreatifitas dalam bekerja dan menyelesaikan permasalahan serta dinamisnya dalam proses bekerja.

Ditemukannya instrumen tes untuk mengukur tingkat kemampuan atau mendeteksi tipe kecerdasan seseorang berada pada belahan dan lapisan otak yang mana, dengan memadukan hasil dari teori dengan keilmiahan dan kondisi pra ilmiah. Instrumen ini dapat digunakan dari usia yang sangat dini. yaitu ditemuakannya alat pemindai sidik jari yang dikenal dengan STIFIn Test yang ditemukan oleh Prof, Farid Poniman. Instrumen yang ditemukan ini mampu

\footnotetext{
${ }^{1}$ HR. Al-Bukhori. No. Hadis: 4402.

2 Achmad Munib. "Konsep Fitrah dan Implikasinya dalam Pendidikan Manusia," Jurnal Progress, Vol. 5, No. 2, 2017.

${ }^{3}$ Ramayulis, "Filsafat Pendidikan Islam". (Jakarta: Kalam Mulia, 2008). hlm. 28.

${ }^{4}$ dalam M. Quraisy Shihab. “Tafsir al-Misbah”, (Jakarta: Lentera Hati, 2016), hlm. 154.
} 
mendeteksi belahan dan lapisan otak seseorang yang dominan, hasil dari pemindaian inilah yang akan memberikan beragam informasi yang cukup kompleks terhadap seseorang terkait dengan keilmiahan metode STIFIn yang dipaparkan, banyak teori yang cukup relevan dengan kekuatan yang dimiliki oleh hasil pemindaian sidik jari, atau dengan kata lain bahwa antara sidik jari dan otak memang memiliki hubungan yang cukup tinggi, sebagaimana dijelaskan oleh dr. Montalcini dan dr. Stanley Cohen yang dikutip oleh Ifa Misbach, ada hubungan antara Epidermal Growth Factor (EGF) dan Nerve Growth Factor (NGF) yang menunjukkan adanya relevansi antara sidik jari dan otak.

Oleh karena itu, dengan menganalisis titik syaraf yang ada di setiap ujung jari, kita bisa menemukan cara kerja otak yang tercermin dari titik syaraf tersebut. Setiap jari memiliki relevansi dengan cerebral korteks (5 bagian dari otak besar), yaitu jempol dengan lobus prefrontal, telunjuk dengan lobus frontal, jari tengah dengan lobus parietal, jari manis dengan lobus temporalis, dan jari kelingking dengan lobus oksipitalis. Setiap lobus pada cerebral korteks ini memiliki fungsi yang berbeda-beda dan merupakan bagian dari otak yang berkaitan dengan potensi bakat. 5

Sejauh ini sudah ada beberapa penelitian yang memanfaatkan metode analisa sidik jari untuk memperoleh gambaran tentang individu. Mostaf Najafi meneliti tentang hubungan antara pola jari digit II dan tingkat kecerdasan pada remaja. Hasil penelitian menunjukan adanya hubungan antara beberapa pola dermatoglyphic diamati pada digit II kanan dengan tingkat IQ pada remaja. ${ }^{6}$ Seile Yohannes, dkk meneliti tentang Biomarker Ermatoglyhic dan penanganan fungsional dalam intelegensi ganda. Hasil penelitian mengungkapkan bahwa kecerdasan dan pola sidik jari berkorelasi terutama dengan pola pada jari tengah kanan, ibu jari kiri, tengah kiri. ${ }^{7}$ Yunyu Zhou, kk meneliti tentang pengembangan aplikasi dan cetak telapak tangan. Hasil penelitian menunjukan bahwa adanya perbedaan yang besar antara cetak telapak tangan dengan sidik jari, cetakan telapak tangan tidak dapat dijadikan sebagai indeks untuk menggambarkan gangguan medis. Penelitian merekomendasikan pengembangan temuan, hubungan sidik jari dengan kecerdasan, hubungan sidik jari dengan pertumbuhan dan identifikasi sidik jari. ${ }^{8}$

${ }^{5}$ Ifa H. Misbach, "Dahsyatnya Sidik Jari: Menguak Bakat dan Potensi untuk Merancang Masa Depan Melalui Pingertprint Analysis", (Jakarta: Visi Media, 2010). hlm. 43.

${ }^{6}$ Mostaf Najafi, "Association between Finger Patterns of Digital II and Intelligence Quotient Level InAdolescents", European Psychiatry, Vol. 25, No. 3, 2009. hlm. 1.

7 Seile Yohannes, dkk, "Dermatoglyphic Biomarkers \& Functional Handedness in Multiple Intelligence", International Journal of Current Research, Vol. 7, No. 08, 2015. hlm. 8.

8 Yunyu Zhou, dkk. "Application and Development of Palm Print". Technology and Health Care, 2002. hlm. 383-390. 
Selanjutnya Anatoly Bikh, dkk menjelaskan tetang hubungan tanda-tanda Dermatoglypic dan tipe temperamen pada manusia, temuan penelitian, mengungkapkan bahwa pola papiler orang dengan berbagai tempramen dapat dijadikan sebagai acuan untuk menentukan karakteristik seseorang dari jenis dermatoglyphic tertentu. ${ }^{9}$ Jen-Feng Wang, dkk meneliti hubungan antara Dermatoglyphics dan Schizopherenia. Hasil penelitian menunjukan bahwa tidak ditemukanya hubungan yang signifikan secara statistik antara Dermatoglyphics dan Shizopherenia, namun ditemukanya perbedaan asimetris yang lebih tinggi pada kelompok pasien eksperimen dibanding kelompok kontrol.10 Schneider meneliti tentang pertumbuhan pola dermatoglyphic pada anak hingga remaja. Temuan penelitian menunjukan keberhasilan dalam menemukan kecocokan sidik jari individu sejak pertumbuhan dan perkembangan mulai dari anak-anak sampai remaja, hasil penelitian merekomendasikan untuk eksplorasi temuan dimasa depan. ${ }^{11}$

Fenomena masih pro kontra dari STIFIn tes ini juga menjadi salah satu hal yang menarik bagi peneliti untuk mengupas teori Farid Poniman dan mengkorelasikanya dengan bimbingan karir yang tepat sesuai dengan hasil Tes STIFIn tersebut serta korelasinya dengan konsep keIslaman tentang potensi manusia. Sebagaimana telah disinggung di atas, bahwa indikatorindikator yang diungkap dari hasil tes STIFIn ini merupakan indikator yang sangat penting dalam mendalami dan mengarahkan ke arah mana karir seseorang sehingga profesi ataupun pekerjaan yang merupakan bagian dari tahapan atau alur karir itu sendiri dapat dijalani dengan sukses, menyenangkan dan sesuai dengan kondisi kemampuan fisik atau jasmaniah dan kemampuan psikologi atau rohaniah individu yang tengah menjalani karir tersebut.

\section{METODE}

Metode yang digunakan dalam penulisan artikel ini menggunakan metode studi kepustakan. Ini dilakukan dengan cara menganalisis konsep-konsep, referensi atau sumber yang berkaitan dengan gagasan dan permasalahan yang diangkat dalam tulisan. Selanjutnya hasil dari telaah terhadap konsep hasil bacaan dianalisis, diambil inti sarinya dan dilakukan proses reduksi hasil pengkajian referensi data dan mengkorelasikannya dengan gagasan dan konsep dari referensi. Menurut Mardelis penelitian kepustakaan atau library reasearch merupakan penelitian yang menggunakan telaah dan kajian kepustakaan atau konsep-konsep

${ }_{9}^{9}$ Anatoly Bikh, dkk, "Analysis of Dermatolyphic Signs for Definition Psychic Functional State of Humans Organism", Information Science and Computing: Internasional Book Series, 2007. hlm. 52.

10 Jen-Feng Wang, dkk. "Derermining the Assosiaciotion between Deratoglyphics and Schizophrenia by Using Fingerprint Asymetry Measures", International Journal of Pattern Recognition and Artificial Intelligence, Vol. 22, No. 3, 2008.

11 Schneider, "Quantifying the dermatoglyphic Growth Patters In Children through Adolescence", Laporan Hibah Penelitian Kantor Kehamiman Amerika Serikat. Tidak diterbitkan, 2005. hal. 1. 
teoritis. ${ }^{12}$ Dalam penulisan artikel ini menggunakan model library research sederhana yang kajiannya ditelaah, dianalisi dan dikorelasikan dengan fenomena atau permasalahan yang dibahas dalam tulisan, sehingga menghasilkan suatu gagasan baru yaitu bimbingan karir terkait proses dan langkah serta materi bimbingan yang direlevansikan dengan Mesin Kecerdasan (MK) Farid Poniman.

\section{HASIL DAN PEMBAHASAN}

\section{STIFIn Test}

\section{a) Sejarah STIFIn Test}

Perjalanan konsep STIFIn telah dilakukkan sejak tahun 1999. Di awali oleh Farid Poniman, sebagai penemu atau pendiri dari STIFIn. Kemudian, diikuti oleh pakar lain: Indrawan Nugroho, Jamil Azni, dan sebagai tim pengagas Kubik Leadership di sebuah lembaga Training. Hal yang melatar belakangi lahirnya STIFIn test itu sendiri dimulai dari lembaga ini, yaitu dari proses pemetaan peserta training setiap kali mengadakan pelatihan, sesuai dengan jenis kecerdasnnya. Ini adalah babak baru dimulainya proses perkembangan STIFIn Test yang kala itu masih berwujud embrio. Tesis atau hipotesisi beliau sudah mengukuhkan bahwa manusia dibekali dengan kecerdasan genetik, yang pada awal kelahirnya itu ada empat jenis kecerdasan yang dideteksi yaitu, S, T, I dan F yang tuangkan dalam bentuk buku Best Seller yang berjudul Kubik Leadership, kemudian dituangkan lagi ke arah yang hampir sempurna pada buku DNA Sukses Mulia. Seiring penyempurnaan hasil dari reset yang beliau lakukan maka ditemukan lima kecerdasan genetik pada mausia yang dikenal dengan STIFIn. ${ }^{13}$

\section{b) Konsep Dasar STIFIn Test}

Sebagaimana telah disinggung sebelumya, bahwa STIFIn test merupakan intrumen tes yang digunakan dengan cara menscan atau memindai sidik jari. Sebagaimana dijelaskan oleh Farid Poniman bahwa tes STIFIn merupakan tes yang dilakukan dengan cara menscan kesepuluh ujung jari seseorang, hasil pindaian atau scan dari sidik jari tersebut dapat memberikan informasi tentang komposisi susunan syaraf seseorang dan dapat etridentifikasi belahan otak mana yang dominan, yang akan menjadi mesin kecerdasan seseorang. Proses pemindaian dilakukan sangat singkat mengambil waktu kurang lebih 1 menit. Konsep teori STIFIn dikembangkan dari riset terhadap beberapa teori psikologi, neuroscience dan ilmu SDM. Yang mengacu pada konsep kecerdasan tungggal Carl Gustaav Jung.

STIFIn merupakan teori yang dibangun dari gabungan tiga teori, Teori fungsi dasar S-T-IF dari C.G.Jung (1875-1959) teori belahan otak atau The Whole Brain Concept dari Ned Hermann, dan Teori Triune Brain dari Paul MacLean (1976).7 Teori STIFIn hasil dari penggabungan teori di

12 Mardelis. "Metode Penelitian Suatu Pendekatan Proposal", (Jakarta: Bumi Aksara, 2004), hlm. 28.

${ }^{13}$ Farid Poniman, "STIFIn Personality", (Bekasi: Yayasan STIFIn, 2017). hlm. 25. 
atas, sehingga cukup relevan dengan tori Myers-Bringgs Theory Indicator (MBTI) yang dikenal sebagai sekala dalam proses seleksi yang dilakukan dalam rekrutmen pegawai, namun hasilnya berdasarkan hasil dari penilaian diri terhadap hasil pengalaman dan persepsi dari proses belajar, sedangkan tes STIFIn merujuk pada hasil genetik secara utuh yaitu dengan memindai 10 sidik jari dengan waktu yang sangat efisien, kurang lebih hanya membutuhkan waktu 2 menit saja. Hubungan atau relevansi bimbingan karir berdasarkan hasil Tes STIFIn, sangat efektif.

Berdasarkan penjelasan dan uraian di atas bahwa STIFIn tes dengan akurasi atau tingkat validitas dan reliebelitas yang sudah terukur, berdasarkan hasil pengukuran atau riset dari 500 sample yang dites, kemudian beberapa bulan kemudian di tes kembali ternyata hasilnya cukup signifikan angka reliabilitasnya di atas $60 \%$. Selanjutnya berdasarkan hasil pemetaan mesin kecerdasan bahwa hasil dari STIFIn tes dikelompokan menjadi 5 jenis Mesin Kecerdasan yang dipecah lagi berdasarkan energi yang membangun kecerdasan itu menjadi 9 jenis mesin kecerdasan, yang masing-masingnya akan ada yang dominan dalam diri individu. Hasil ini sudah dapat diidentifikasi sejak anak berusia 13 minggu, namun yang paling baik pada usia anak tiga tahun.

Seperangkat komputer yang digunakan untuk proses STIFIn test terdiri dari elemen hardware dan softwear, elemen hardware ditugaskan untuk merekam sidik jari dari sepuluh jari tangan seseorang untuk dikaitkan dengan unsur neourologi pada bagaian otak peserta tes. Rekaman sidik jari inilah yang kemudian diterjemahkan oleh sofwere yang akan menganalisa dan menyimpulkan jenis kecerdasan beserta keperibadian atau karakteristiknya. Berbagai informasi yang dapat dihasilkan dari proses pemindaian ini sangat banyak, mulai dari metabolisme tubuh, struktur tubuh, kekuatan dan kelemahan diri, pasangan kemistri, unsur alami, cara belajar, kesesuaian profesi, cara bekerja, cara berkomunikasi dan cara sukses menjalani hidup. Indikator-indikator ini tentunya sangat penting untuk diketahui dan dikenali, sehingga akan memudahkan seseorang untuk mengarahkan ke jenis karir dan pekerjaan tertentu.

\section{c) Karakteristik Mesin Kecerdasan STIFIn Test}

Kekhasan dari tes STIFIn adalah adanya kesesuain hasil dari proses pemindaian sidik jari yang berlangsung cukup singkat, namun hasilnya cukup akurat, sebagaimana hasil survei sederhana dari penulis lakukan kepada sepuluh orang yang melakukan tes tersebut mengaku bahwa hasil yang dihasilkan dari proses pemindaian sidik jari tersebut cukup akurat, namun ada beberapa indikator dan karaktersitik diri yang kurang menonjol dan tidak dikembangkan. 
Di dalam tes STIFIn ada dua hal yang dicari untuk memetakan kecerdasaan seseorang14 yaitu, mencari dimana belahan otak yang dominan yang nantinya akan berfungsi sebagai mesin kecerdasan itu sendiri, serta dimana lapisan otak yang dominan yang nantinya akan berfungsi sebagai lapisan otak yang berfungsi sebagai kendali draver atau pilot dari mesin kecerdasan tersebut), dari hasil ini akan dipetakan atau dikelompokan lagi menjadi lima jenis Mesin Kecerdasan yaitu

i. Sensing intertrovert (Si), merupakan MK yang dikendalikan oleh sistem oprasi otak berada di belahan otak bagian bawah di sebelah kiri (limbik kiri) dan kemudi kecerdasannya berada pada lapisan limbik kiri putih. Kekhasan yang dimiliki oleh Si adalah Persisitent, Detaled, Recorder, Discipline, Careful, Spirited, Encycloped, Workaholic, Timefu, Indifferent. Arah pendidikan atau karir bidang Keuangan, Bahasa, Transportasi, Perdagaangan, Hiburan, Ekonomi, Atlet, Tetara, Sejarawan, Bangkir, Dokter, Pertanahan, Jurnalis, Administrasi, Pustakawan, security, fotografer, persenter, cameramen, dan pekerja lapangan.

ii. Sensing ektrovert (Se), merupakan mesin Kecerdasan yang dikendalikan oleh sisitem oprasi otak berada di belahan otak bagian bawah disebelah kiri (limbik kiri) dan kemudi kecerdasannya berada pada lapisna limbik abu-abu, kekhasan yang dimiliki oleh Se adalah adventurous,, playful, demonstrative, generous, repetitious, tune in order, show offs, inoffensive, endurance, experience. Arah pendidikan atau karir bidang ekonomi, sport, kemiliteran, perhotelan, sejarah, ahli bahas, ahli keuangan, pedagang, entertainer, bankir, pertahanan, dokter, Jurnalis, pilot, salesman, perkebunan, pertanian, administrasi, sekretaris, oprator, pekerja pabrik, security, dan pekerja lapangan dalama berbagai bidang.

iii. Thinking iktrovert (Ti), merupakan mesin Kecerdasan yang dikendalikan oleh sistem oprasi otak berada di belahan otak bagian atas di sebelah kiri (otak kiri) dan kemudi kecerdasannya berada pada lapisan putih bagian dalam. Kekhasan yang dimiliki oleh Ti adalah expert, on time, scheduled, independent, focus, through, mechanistic, prudent, responsible, scheme. riset dan teknologi, Arah pendidikan atau karir bidang utama informasi, teknologi, pertambangan, konstruksi, kesehatan, garmen dan arah karir pilihan; Manajer, manufactur, bisnis, properti, peternakan, penelitian, perminyakan, programmer, dokter, apoteker, fisikawan, insinyur, dosen atau guru, birokrat, ahli strategi, pelatih bola, pembuat kebijakan, ahli rekayasa, developer, konsultan manajemen atlit pertandingan.

${ }^{14}$ Farid Poniman, dkk. "9 Personaliti Genetik”, (Jawa Barat: Yayasan STIFIn, 2017). hlm. 35. 
iv. Thinking ekstrovert (Te), merupakan mesin Kecerdasan yang dikendalikan oleh sistem oprasi otak berada di belahan otak bagian atas disebelah kiri (otak kiri) dan kemudi kecerdasannya berada pada lapisan abu-abu bagian luar. Kekhasan yang dimiliki oleh Te adalah thoughtful, analytical, competitive, reserved, planner, positif, argumentative, forceful, formal, justice. Arah pendidikan atau karir bidang utama Manajemen kepemerintahan, manufacturing, properti, peternakan. Arah karir pilihan; Ristek IT, bisnis, pertambangan, ahli konstruksi, bisnis kesehatan, garmer, peneliti, fabrikan, perminyakan, programer, dokter, apoteker, ekonomi, manajer, dosen atau guru, property, insinyur, fisikawan, kimiawan, konsultan managemen, teknokrat, birokrat, pajak, produsen, quality control, auditor, ahli strategi, system analis, ahli rekayasa, developer, atlit pertandingan.

v. Intuting introvert (Ii), merupakan mesin Kecerdasan yang dikendalikan oleh sistem oprasi otak berada di belahan otak bagian atas sebelah kanan, (otak kanan) dan kemudi kecerdasannya berada pada lapisan putih bagian dalam. Kekhasan yang dimiliki oleh Ii yaitu; learner, assertive, perfectionist, scholar, hard to please, proud, optimistic, deep, insistent, capable selling. Arah pendidikan atau karir utama, marketing atau periklanan, lifestyle, mode, penerbangan, agroforesty. Arah karir pilihan pada bidang, pengusaha/investor, bisnis, pendidikan atau pelatihan, penulis sastra, cenematrografis, detektif, seniman, pengusaha, peneliti sains murni, fisikawan, quantum, pencipta lagu, reengineering, proyeksi, peramal, bisnis, pemain saham, investor filosuf, pakar pembelajaran atau pemodul, event organizer, produsen, arsitek, sutradara, desainer, pelukis abstrak, pesulap, peramal, dan pelatih pertandingan penyembuh cenayang, pialang saham, dan atlit. Bidang.

vi. Intuiting ektrovert (Te), merupakan mesin Kecerdasan yang dikendalikan oleh sistem oprasi otak berada di belahan otak bagian atas sebelah kanan, (otak kanan) dan kemudi kecerdasannya berada pada lapisan abu-abu bagian luar. Arah pendidikan atau karir utama dari tipe Ii adalah; kewirausahan, investasi, pendidikan atau pelatihan, sastra, cinematografi, spionase atau kepolisian. Bidang karir pilihan, iklan agency, lifestly mode, bisnis penerbangan, bisnis agro forenstry, seniman, pengusaha, peneliti sain murni, fisikawan quantum, pencipta lagu, reengineering, proyeksi, peramal bisnis, pemain saham, investor, filosof, pakar pembelajaaran/pemodul, Even Organizer, produsen, sutradara, pelukis abstrak, penyembuh, peramal, pialang saham.

vii. Feeling Introvert (Fi), merupakan Mesin Kecerdasan yang dikendalikan oleh sisitem oprasi otak berada di belahan otak bagian bawah di sebelah kanan (limbik kanan) 
dan kemudi kecerdasannya berada pada lapisan limbik putih bagian dalam, kekhasan yang dimiliki oleh $\mathrm{Fi}$ adalah idealistic, leader, kindful, reflective, convincing, promotor, diplomatic, friendship appleal. Arah pilihan studi atau karir yang utama adalah; politik, kepemerintahan, hukum, seniman. Arah karir pilihan, psikolog, komunikasi, diplomat, humas, promor, investor, negarawan, trainer atau public speaker, administrasi negara, seniman, budayawan, HI, salesmen, inspirator, motivator, psikiater, konselor, ideolog, personalia, aktivis, atelit maraton.

viii. Feeling ektrovert (Fe), merupakan Mesin Kecerdasan yang dikendalikan oleh sisitem oprasi otak berada di belahan otak bagian bawah disebelah kanan (limbik kanan) dan kemudi kecerdasannya berada pada lapisna abu-abu bagian luar. Kekhasan yang dimiliki oleh Fe adalah emphathy, tolerant, communicative, listener, symphathetic, persuasive, affectionate, enable, considerate, guiding. Arah pilihan studi atau karir yang utama adalah; Psikolog, komunikasi, diplomasi, humas atau promosi. Arah karir pilihan, politisi, eksekutif, lawyer, kesenian, investor, negarawan, trainer/ publik speaker, administrasi negara, seniman, budayawan, hubungan Internasional, salesmen, inspirator, motivator, psikiater, counselor, ideolog, personalia, birokrat, aktivis, atlit marator, kesembilan,

ix. Instinct (In) mesin kecerdasana yang unik dan khas dibading 8 mesin kecerdasan sebelumnya, karena berdiri sendiri tidak memiliki kemudi dari dalam maupun dari dalam, karena mesin kecerdasan ini berada di bagian tengah (Otak tengah). Kekhasan dari In adalah balanced, compromising, peaceaful, resourceful, simple, forgiving, occupied, flowing, smooth, intermediary. Arah pilihan studi atau karir utama, yaitu; Musik atau Performance, Jasa, Kulinery, Agama atau budaya atau Chairity. Arah bidang karir pilihan, yaitu; pembalap, entertainer, agamawan, aktivis, musik, chef, jurnalis, aktivis, pengetahuan umum, performan $\mathrm{Ce}$, spritualitas, birokrat, pelayanan masyarakat, mediator, tangan kanan untuk semua posisi, persentre serba bisa, atlit serba bisa.

\section{Bimbingan Karir}

Bimbingan karir merupakan salah satu bidang pengembangan dalam Bimbingan dan Konseling. Dalam sejarah Bimbingan dan Konseling, bimbingan karir merupakan perintis dari pelaksanaan layanan konseling yang dilakukan. Berdasarkan sejarah di Amerika bimbingan Konseling dilatar belakangi dengan kondisi kemiskinan, dan hilangnya pekerjaan, pasca meletusnya perang dunia kedua, Latar belakang pengembangan proses bimbingan karir pada saat itu, banyak yang kehilangan pekerjaan, dan kemiskinan melanda. Untuk di Amerika 
Bimbingan karir sudah berkembangan sejak tahun 1901-an, sedangkan di Indonesia bimbingan karir mulai berkembangan memasuki tahun 1981.

Menurut Yusuf bahwa bimbingan karir adalah suatu proses bantuan, terhadap individu, agar dapat mengenal dirinya, memahami dirinya, dan mengenal dunia kerja merencankan masa depan dengan bentuk kehidupan yang diharapkan untuk menentukan pilihan dan mengambil suatu keputusan bahwa keputusannya tersebut adalah paling tepat sesuai dengan keadaan dirinya dihubungkan dengan persyaratan dan tuntutan pekerjaan atau karier yang dipilihnya. ${ }^{15}$ Menurut Winkels dan Sri Astuti, bimbingan karier merupakan bimbingan dalam mempersiapkan diri menghadapi dunia kerja, dalam memilih lapangan kerja atau jabatan atau profesi tertentu serta membekali diri supaya siap memangku jabatan itu, dan dalam menyesuaikan diri dengan tuntutan kompetensi yang harus dikuasai oleh suatu pekerjaan yang dimasuki. ${ }^{16}$

Selanjutnya berdasarkan beberapa konsep dari beberapa pengertian yang dipaparkan bimbingan karir adalah proses bantuan terhadap individu agar dapat mengenal dan memahami dirinya, mengenal dunia kerjanya, mengembangkan masa depan sesuai dengan kehidupan yang diharapkannya, serta mampu mengambil keputusan secara tepat dan bertanggung jawab. Tahapan dalam bimbingan karir, yaitu sebagai berikut: pertama, pada jenjang pendidikan dasar bimbingan karir berorietasi pada penyadaran karir, kedua, ada jenjang pendidikan menengah pertama ekplorasi karir, ketiga, ada jenjang pendidikan menengah atas di lakukan persiapan karir, selanjutnya yang keempat, pada jenjang perguruan tinggi sudah merupakan tahap dasar pemilihan profesi sesuai dengan jurusan dan program studi yang diminati.

Proses penyadaran karir ini bisa dilakukan dengan hal-hal yang sederhana, misalnya dengan mengidentifikasi cita-cita, kecenderungan dan minat, serta mengklasifikasi dan identifikasi pekerjaan atau profesi dari orang-orang terdekat, misalnya dari orang tua, guru, dan kakak atau saudara di rumah, dan dapat juga melaui kegiatan karya wisata ke beberapa pusat perkantorkan untuk mengorientasi beragam jenis bidang profesi, serta mengembangkan karakter dan kepribadian yang akan menjadi tuntutan dari profesi tersebut, misalnya untuk menjadi seorang guru harus menggembangkan sikap yang ramah, penyayang, bijaksana dan beberapa karkater unggul lainnya.

Selanjutnya untuk tingkat sekolah menengah pertama yang merupakan tahap eksplorasi dari proses bimbingan karir, dapat dilakukan dengan cara lebih mengidentifikasi minat bakat,

\footnotetext{
15 A. Muri Yusuf. "Kiat Sukses dalam Karier", (Padang: Galiah Indonesia, 2002). hlm. 44.

${ }_{16}$ Winkels dan Sri Hastuti, "Bimbingan dan Konseling di Institusi Pendidikan", (Jakarta: Gramedia. 2005), hlm. 363.
} 
melalui beragam istumen atau asessment, misalnya tes peminatan, tes IQ tes yang dapat mengungkap kecenderungan dan kompetensi dasar yang dimiliki. Dalam tahap ini sudah dapat dilakukan dengan berbagai layanan lain, misalnya melalui layanan bimbingan kelompok. Saling bertukar pikiran dan informasi, berdiskusi terkait beragam jenis jabatan atau karir tertentu yang dapat dicapai dan direlevansikan dengan sikap atau karater yang disyaratkan oleh karir tersebut.

Selanjutnya tahap jenjang pendidikan menengah atas, merupakan tahap persiapan, pada jenjang pendidikna ini individu sudah diklasifikasikan berdasarkan minat dan kecenderungan tertentu, misalnya terkait jurusan Ilmu Pengetahuan Alam, Ilmu Pengetahuan Sosial, teknik mesin, listrik bangunan atau di sekolah menengah kejuruan, komputer dan informatika, komputer jaringan tataboga dan tata rias, selanjutnya sudah disiapkan untuk proses magang kerja sesuai dengan jurusan yang ditempati. Selanjutnya untuk jejang pendidikan perguruan tinggi, bimbingan karir sudah lebih luas dan lebih sfesifik, misalnya sudah tersedia layanan khusus, laboratorium karir, pusat bimbingan karir (Carier Centre) yang memfasilitasi kebutuhan informasi dan pengembangan skill atau kompetensi mahasiswa. Sehingga dapat benar-benar menyiapkan diri dengan tuntutan dunia pekerjaan, atau lebih focus untuk dapat berkontribusi dalam mengisi lapangan pekerjaan, inti bimbingan karir pada jenjang pendidikan tinggi adalah pemantapan karir.

Kesimpulan untuk tahapan bimbingan karir yang sudah terpola dan memiliki tahap atau jenjang mulai dari tahap pendidikan dasar, yang merupakan tahap penyadaran karir, tahap pendidikan menengah pertama, tahap ekplorasi karir, tahap pendidikan menengah atas tahap persiapan karir dan tahap pendidikan perguruan tinggi, pemantapan karir. Berdasarkan hasil STIFIn test, tahap identifikasi kecenderungan atau ekplorasi karir sudah dapat dilakukan pada tahap yang sangat dini, yaitu mulai dari usia enam bulan, sudah dapat diidentifikasi mengenai bakat-bakat genetik yang ada pada anak, sehingga proses parenting, dan pendidikan akan lebih terarah.

\section{Relevansi Bimbingan Karir STIFIn Test}

Dalam penjelasan sebelumnya poin penting dalam proses bimbingan karir adalah proses bantuan pada individu untuk dapat mengenal dan memahami dirinya, mengenal dunia kerjanya, dan mampu menentukan dan mengambil keputusan secara tepat dan bertanggung jawab. STIFIn Test merupakan proses mengidentifikasi mesin kecerdasan seseorang melalui pemindaian kesepuluh sidik jari, sehingga diperoleh belahan dan lapisan otak yang dominan yang sangat penting dalam memberikan informasi terkait metabolisme tubuh, struktur tubuh, kekuatan dan kelemahan diri, pasangan kemistri, unsur alami, tipe belajar, profesi yang matching, cara bekerja, cara berkomunikasi dan cara sukses dalam berkarir secara khusus dan 
dalam kehidupan secara umum. Indikator-indikator ini merupakan indikator yang sangat penting dalam proses, identifikasi, ekspolrasi persiapan dan pematangan atau pemantaban karir individu, sehingga ditemukan kesesuain atau relevansi mesin kecerdasan yang dijelaskan sebelumnya ada 9 jenis mesin kecerdasan yaitu, sensing introvert (Si) sensing ekstrovert (Se), thingking introvert (Ti) dan thingking ekstrovert (Te), intuiting introvert (Ii) dan intuiting ekstrovert (Ie), feeling introvert (Fe), dan feeling ekstrovert (Fe) dan yang terakhir insting (In).

Masing-masing mesin kecerdasan ini memiliki kekhasan tersendiri kekhasan (kelebihan dan kekurangan) masing-masing. Berdasarkan kekhasan inilah dapat diidentifikasi arah studi atau pilihan karir utama pada bidang-bidang tertentu, serta ada beberapa alternatif pilihan studi atau karir yang dapat diambil. Kekhasan ini sudah dapat diidentifikasi sejak anak usia sangat dini sekali, meskipun pada saat itu anak belum memahami tentang dirinya, namun orang tua atau orang-rang disekitarnya yang dapat mengarahkan anak untuk dapat menemukan, mengenali dirinya dengan kecendrungan dirinya, sehingga anak akan jauh lebih matang dan mampu untuk mengambil keputusan karir pada pilihan studi dan pekerjaan nantinya.

Fenomena yang sering terjadi pada tahapan sudah menempati jabatan atau profesi atau karir tertentu seseorang masih merasakan keraguan dan kebimbangan yang luar biasa. Bahkan tidak jarang yang kita temui, individu yang resign dari pekerjaan, padahal jika dilihat dari finansial sudah sangat mempuni, atau posisi jabatan yang strategis, juga banyak yang berpindah-pindah pekerjaan. Di tingkat perguruan tinggi banyak fenomena berpindah-pindah program studi bahkan pindah Universitas dengan jurusan yang berbeda pula.

Tes STIFIn sudah dapat dilakukan sejak anak masih usia enam bulan, tes ini menunjukan hasil yang permanen sekali seumur hidup, sebagaimana hasil penelitian beberapa orang diantaranya Dr. Moordiningsih, M.Si.Psi, telah melakukan tes STIFIn pada waktu yang berbeda dan hasilnya tetap sama. Seperti yang telah disinggung sebelumnya bahwa STIFIn Test merupakan hasil dari beberapa kali penyempurnaan riset yang diakukan oleh Farid Poniman bersama TIM (Indrawan Nugroho dan Jamil Azzaini) sebagai founder dari STIFIn Test, Mengatakan bahwa, gunakan kecerdasan dominan plus fokus (latihan teratur dan terdesain serta konsisten), sedikitnya 10 ribu jam, atau setara dengan 3 tahun. Serta anjuran beliau untuk tidak menghabiskan waktu mengembangkan kecerdasan yang lain, walupun bisa dengan bidang lain, namun ini hanya menyumbang 3\% yang mampu mengoptimalkan semua mesin kecerdasadannya dan $97 \%$ yang bisa dengan satu kecerdasan. ${ }^{17}$

${ }^{17}$ Farid Foniman, dkk. “STIFIn Personality”, hlm. 54. 
Sebagimana telah dijelaskan sebelumnya bahwa bimbingan karir merupakan proses bantuan layanan, pendekatan terhadap individu agar dapat mengenali, memahami, bakat minat yang dimiliki (segenap potensi yang dimiliki), untuk dapat mencocokannya dengan bidang pekerjaan atau profesi seorang mengenali, bidang pekerjaan yang dijalani. Yusuf mengatakan bahwa tujuan dari bimbingan karir adalah; 1) memiliki pemahaman terhadap potensi diri; 2). Memiliki wawasan dan pengetahuan yang luas tentang dunia kerja dan informasi karir yang menunjang kematangan kompetensi; 3). Memahami hubungan kemampuan menguasai skill dengan tuntutan bidang pekerjaan atau profesi tertentu); 4) memiliki sikap positif terhadap profesi dan pekerjaan yang dijalani, ${ }^{18}$ Berdasarkan tujuan tersebut maka untuk STIFIn Test sangat mudah dalam mewujudkan empat tujuan dari proses bimbingan karir di atas.

Hasil STIFIn Test yang memetakan kecerdasan individu menjadi lima kecerdasan dan memetakanya berdasarkan karakteristik yang lebih spesifi menjadi sembilan jenis kekhasan atau tipe, yang masing-masingnya memiliki kekuatan dan kelemahan masing-masing, yang menggambarkan cara belajar, karakteristik kepribadian, kemudian arah kecenderungan dan kelemahan, yang bermuara pada arah bidang karir utama ataupun pilihan yang sesuai dengan tipe kecerdasan atau mesin kecerdasan yang sudah dapat diidentifikasi dari usia dini, disamping mengarahkan sekolah atau studinya, hasil STIFIn Test juga sangat bermanfaat dalam mengasuh atau parenting pada anak.

Hal ini akan mempengaruhi kepribadian anak dalam mengembangkan kecerdasan yang sudah teridentifikasi, sehingga pada tahapan langkah-langkah atau tahapan karir yang sudah dibahas sebelumnya mulai dari tahap kesadaran karir, yang dilakukan di tahapan sekolah dasar sudah sangat memungkinkan dilakukan dengan cara menstimulus atau memberikan rangsangan pada anak sesuai dengan mesin kecerdasannya, selanjutnya pada pedidikan menengah pertama, juga sudah sangat tepat diarahkan studinya ke arah yang sesuai dengan potensi yang dimiliki.

Tahap eksplorasi yang sudah cukup efisien sebelumnya sudah dikenali mesin kecerdasan dari usia yang dini, sehingga eksplorasi terhadap keunggulan diri sudah dapat direlevansikan dengan eksplorasi bidang pekerjaan atau profesi yang akan dijalani nantinya, selanjutnya tahap persiapan yang berlansung pada sekolah menengah atas, cukup mudah dilakukan ketika anak sudah menemukan kemistri dan kenyamanan pada kompetensi yang dimiliki dan bidang profesi atau pekerjaannya yang sudah nyaman dan sesuai dengan mesin kecerdasan yang dimiliki. Selanjutnya pada tahap pemantapan atau kematangan karir, karena identifkasi dan

18 A. Muri Yusuf. "Konseling Karier dalam Satuan Pendidikan dan Praktik Pribadi", (Padang: Universitas Negeri Padang, 2006), hlm. 15. 
penyesuaian serta eksplorasi sudah dilalui dengan baik sehingga pada tahapan ini sudah sangat valid. Sehingga tidak ditemukan lagi permasalahan pindah program studi, resign dari pekerjaan, dan merasa tidak nyaman dengan pekerjaan yang dijalani. Kontribusi dari relevansi antara kompetensi yang dimiliki dengan bidang profesi atau pekerjaan yang dijalani, tentu meningkatkan produktifitas kerja yang berkualitas.

Sebagaimana telah dijelaskan sebelumnya, bahwa dalam Islam pada hakikatnya manusia yang dilahirkan ke dunia merupakan makhluk yang paling sempurna, sebagaimana dijelaskan dalam Al-Qur'an surah At-Tin: 4 bahwa Allah telah menciptakan manusia dalam bentuk yang sebaik-baiknya. Dalam surah tersebut terkadung makna, bahwa sejatinya tidak ada manusia yang bodoh. Selanjutnya dalam hadis juga dijelaskan bahwa manusia dilahirkan dalam keadaan fitrah. Beberapa Ahli tafsir memaknai kata fitrah sebagai potensi laten atau potensi dasar yang dibawa manusia sejak lahir. Penjelasan tersebut sangat relevan sekali bahwa pada dasarnya manusia memiliki potensi dasar atau potensi genetis yang telah dibekali sejak lahir, untuk dapat dikembangkan dalam menjalankan profesi dan karirnya.

\section{KESIMPULAN}

Bimbingan karir berdasarkan telaah teori STIFIn Farid Poniman, sebagai usaha untuk menyesuaikan antara mesin kecerdasan yang terdeteksi melalui proses pemindaian sidik jari dari sepuluh jari tangan, melalui proses pemindaian tersebut akan diperoleh gambaran bidang karir atau arah studi yang sesuai dengan masing-masing mesin kecerdasan tersebut. Dengan demikian maka akan diperoleh kenyamanan, daya produktifiatas dalam bekerja karena sesuai dengan potensi yang dimiliki, dan akan terbentuk kemistri yang baik dengan profesi atau pekerjaan atau karir yang ditempati. Dalam hal ini ada lima jenis Mesin Kecerdasan seseorang, yang diambil dari singkatan nama intrumen yang digunakan yaitu, Mesin Kecerdasan Sensing (Si dan Se), Thingking (Ti dan Te), Intutiting (Ii dan Ie), Feeling (Fi dan Fe), serta Insting mesin kecerdasan yang berdiri sendiri tanpa kemudi yang dominan.

Selanjutnya pada tahapan proses bimbingan karir, proses Tes STIFIn merupakan tahapan ekplorasi karir, yang sudah dapat dilakukan sejak usia anak enam bulan. Namun sebaiknya pada usia 3 tahun atau dilakukan sejak dini, sehingga mengarahkan individu sesuai dengan bidangnya tentu akan lebih muda, sehingga akan mengurangi kesalahan dalam memilih program sudi atau jurusan saat memasuki sekolah menengah sampai ke Perguruan Tinggi, dengan demikian secara tidak langsung akan memberikan kontribusi terhadap produktifitas dalam bekerja.

Dalam Islam teori STIFIn tentunya sangat relevan sekali dari beberapa ayat yang menjelaskan bahwa manusia yang dilahirkan ke dunia merupakan makhluk yang paling 
sempurna di antara ciptaan Allah SWT yang lain. Selanjutnya penjelasan ayat tentang manusia adalah insan yang telah diciptakan Allah dalam bentuk yang sebaik-baiknya, manusia dilahirkan dalam keadaan fitrah, dengan membawa potensi dasar yang dapat dikembangkan dalam proses dan tahapan perkembangan dan pertumbuhan manusia, sehingga benar-benar mampu menjadi insan yang sempurna, yang mampu menjadi khalifah atau pemimpin bagi diri sendiri dan orang lain. Selanjutnya dalam salah satu hadis juga dijelaskan bahwa pada hakikatnya manusia terlahir dalam keadaan fitrah. Ahli tafsir memaknai fitrah di sini sebagai kesucian, kebaikan dan juga potensi. Jelaslah dalam Islam pada dasarnya semua insan memiliki potensi yang dapat dikembangkan. Potensi ini dapat dimaknai sebagai kecerdasarn, minat dan bakat atau kecenderungan, sehingga dapat menjadi insan yang sempurna dan paripurna.

\section{DAFTAR RUJUKAN}

Bikh Anatoly, dkk, “Analysis of Dermatolyphic Signs for Definition Psychic Functional State of Humans Organism", Information Science and Computing: Internasional Book Series, 2007.

HR. Al-Bukhori. No. Hadis: 4402.

Mardelis. "Metode Penelitian Suatu Pendekatan Proposal”, Jakarta: Bumi Aksara, 2004.

Misbach, Ifa H, "Dahsyatnya Sidik Jari: Menguak Bakat dan Potensi untuk Merancang Masa Depan melalui Pingertprint Analysis", Jakarta: Visi Media, 2010.

Munib, Achmad. “Konsep Fitrah dan Implikasinya dalam Pendidikan Manusia," Jurnal Progress, Vol. 5, No. 2, 2017.

Najafi, Mostaf, "Association between Finger Patterns of Digital II and Intelligence Quotient Level InAdolescents", European Psychiatry, Vol. 25, No. 3, 2009.

Poniman, Farid, “STIFIn Personality”, Bekasi: Yayasan STIFIn, 2017.

Poniman, Farid, dkk, "9 Personaliti Genetik", Jawa Barat: Yayasan STIFIn, 2017.

Ramayulis. "Filsafat Pendidikan Islam". Jakarta: Kalam Mulia, 2008.

Schneider, "Quantifying the dermatoglyphic Growth Patters In Children through Adolescence", Laporan Hibah Penelitian Kantor Kehamiman Amerika Serikat. Tidak diterbitkan, 2005.

Shihab, M. Quraisy. “Tafsir al-Misbah”, Jakarta: Lentera Hati, 2016.

Yohannes, Seile, dkk, "Dermatoglyphic Biomarkers \& Functional Handedness in Multiple Intelligence", International Journal of Current Research, Vol. 7, No. 08, 2015.

Yusuf, A. Muri. “Kiat Sukses dalam Karier”, Padang: Galiah Indonesia, 2002.

Yusuf, A. Muri. "Konseling Karier dalam Satuan Pendidikan dan Praktik Pribadi", Padang: Universitas Negeri Padang, 2006, 
JURNAL ILMIAH SYIAR

(15) Jurusan Dakwah, FUAD, IAIN Bengkulu

Wang, Jen-Feng, dkk. "Derermining the Assosiaciotion between Deratoglyphics and Schizophrenia by Using Fingerprint Asymetry Measures", International Journal of Pattern Recognition and Artificial Intelligence, Vol. 22, No. 3, 2008.

Winkels dan Sri Hastuti, "Bimbingan dan Konseling di Institusi Pendidikan”, Jakarta: Gramedia. 2005.

Zhou, Yunyu, dkk. "Application and Development of Palm Print". Technology and Health Care, 2002. 